\title{
Malignant Tenosynovial Giant Cell Tumor: The True "Synovial Sarcoma?" A Clinicopathologic, Immunohistochemical, and Molecular Cytogenetic Study of 10 Cases, Supporting Origin from Synoviocytes
}

\author{
Alyaa Al-Ibraheemi ${ }^{1} \cdot$ William Albert Ahrens $^{2} \cdot$ Karen Fritchie $^{1} \cdot$ Jie Dong $^{1} \cdot$ Andre M. Oliveira $^{1} \cdot$ Bonnie Balzer $^{3}$. \\ Andrew L. Folpe ${ }^{1}$
}

Received: 5 July 2018 / Revised: 31 July 2018 / Accepted: 1 August 2018 / Published online: 11 September 2018

(c) United States \& Canadian Academy of Pathology 2018

\begin{abstract}
We present our experience with ten well-characterized malignant tenosynovial giant cell tumors, including detailed immunohistochemical analysis of all cases and molecular cytogenetic study for CSF1 rearrangement in a subset. Cases occurred in $7 \mathrm{M}$ and $3 \mathrm{~F}$ (mean age: 52 years; range: 26-72 years), and involved the ankle/foot $(n=1)$, finger/toe $(n=3)$, wrist $(n=1)$, pelvic region $(n=3)$, leg $(n=1)$, and thigh $(n=1)$. There were eight primary and two secondary malignant tenosynovial giant cell tumors. Histologically, all cases showed definite areas of typical tenosynovial giant cell tumor. The malignant areas varied in appearance. In some cases, isolated malignant-appearing large mononuclear cells with high nuclear grade and mitotic activity were identified within otherwise-typical tenosynovial giant cell tumor, as well as forming larger masses of similar-appearing malignant cells. Occasionally, these nodules of malignant large mononuclear cells showed transition to pleomorphic spindle cell sarcoma, with varying degrees of collagenization and myxoid change. One malignant tenosynovial giant cell tumor was composed of sheets of monotonous large mononuclear cells with high nuclear grade, growing in a hyalinized, osteoid-like matrix, with areas of heterologous osteocartilaginous differentiation. Mitotic activity ranged from 2 to 34 mitoses per 10 HPF (mean 18/10 HPF). Geographic necrosis was observed in four cases. The malignantappearing large mononuclear cells were consistently positive for clusterin and negative for CD163, CD68, and CD11c. Desmin was positive in a small minority of these cells. Areas in malignant tenosynovial giant cell tumor resembling pleomorphic spindle cell sarcoma or osteo/chondrosarcoma showed loss of clusterin expression. RANKL immunohistochemistry was positive in the large mononuclear cells in eight cases. Two cases showed an unbalanced rearrangement of the CSF1 locus. Follow-up (nine patients; range 0.5-66 months; mean 20 months) showed three patients dead of disease, with three other living patients having lung and lymph node metastases; three patients were disease-free. We conclude that malignant tenosynovial giant cell tumors are highly aggressive sarcomas with significant potential for locally destructive growth, distant metastases, and death from disease. The morphologic and immunohistochemical features of these tumors and the presence of CSF1 rearrangements support origin of malignant tenosynovial giant cell tumor from synoviocytes.
\end{abstract}

Andrew L. Folpe

Folpe.Andrew@mayo.edu

1 Department of Laboratory Medicine and Pathology, Mayo Clinic, Rochester, MN, USA

2 Department of Laboratory Medicine and Pathology, Carolinas HealthCare System, Charlotte, NC, USA

3 Department of Pathology, Cedars-Sinai Medical Center, Los Angeles, CA, USA

\section{Introduction}

Tenosynovial giant cell tumors, described by Jaffe 1941 [1], are relatively common tumors that typically arise in association with the synovium of joints, bursae, or tendon sheaths [2]. Tenosynovial giant cell tumor may be either intra- or extra-articular, and can be divided into localized and diffuse types, based on their growth pattern and clinical behavior [3, 4]. "Pigmented villonodular synovitis" is a synonym for the intra-articular, diffuse form of this disease, whereas the extra-articular, localized variant is also known 
Table 1 Clinicopathological features

\begin{tabular}{|c|c|c|c|c|c|c|c|}
\hline Case & Age/sex & Location & $\begin{array}{l}\text { Primary or secondary } \\
\text { MTGCT }\end{array}$ & Treatment & $\begin{array}{l}\text { Local } \\
\text { recurrence }\end{array}$ & Metastases & $\begin{array}{l}\text { Follow-up/ } \\
\text { duration }\end{array}$ \\
\hline 1 & $32 / \mathrm{M}$ & Thigh & Primary & Resection & No & Lung & AWD/6 months \\
\hline 2 & $61 / \mathrm{M}$ & Finger & Primary & Resection/ radiation & No & No & ANED/15 months \\
\hline 3 & $60 / \mathrm{M}$ & Ankle & Secondary & Amputation & No & $\begin{array}{l}\text { Lung and lymph } \\
\text { node }\end{array}$ & DOD/6 months \\
\hline 4 & $56 / \mathrm{F}$ & Leg & Primary & Resection & No & No & ANED/7 months \\
\hline 5 & $72 / \mathrm{F}$ & Thumb & Primary & Resection & No & No & ANED/5 months \\
\hline 6 & $72 / \mathrm{M}$ & Pelvic & Primary & Resection & No & No & DOD/1 month \\
\hline 7 & $26 / \mathrm{F}$ & Toe & Primary & Resection & No & No & ANED/27 months \\
\hline 8 & $64 / \mathrm{M}$ & Pelvic & Secondary & $\begin{array}{l}\text { Resection/ chemotherapy/ } \\
\text { radiation }\end{array}$ & No & Lung & DOD/66 months \\
\hline 9 & $27 / M$ & Pelvic & Primary & Resection/ Denosumab & Yes & No & AWD/48 months \\
\hline 10 & $46 / \mathrm{M}$ & Wrist & Primary & Resection & Recent & Recent & Recent \\
\hline
\end{tabular}

$A N E D$ alive with no evidence of disease, $A W D$ alive with disease, $D O D$ dead of disease, $F$ female, $M$ male, $M T G C T$ malignant tenosynovial giant cell tumor

as "giant cell tumor of tendon sheath." The morphological features of tenosynovial giant cell tumor in any location are essentially identical, with a distinctive admixture of small histiocytes with rounded, grooved nuclei, larger mononuclear cells with eccentrically placed nuclei, abundant eosinophilic cytoplasm, and a peripheral rim of hemosiderin, osteoclasts, xanthomatous macrophages, lymphocytes, and plasma cells [4-6]. However, the histologic appearance of tenosynovial giant cell tumor may be quite variable, depending on the relative proportion of these various cell types, as well as the extent of stromal collagenization, pseudoglandular change, and cleft-like spaces [4].

Because of their polymorphous nature, tenosynovial giant cell tumor were originally regarded as non-neoplastic, and possibly reactive in etiology $[1,7]$ [8]. However, in 2006, West et al. [9] showed that rearrangements of the macrophage colony-stimulating factor gene, CSF 1, most often with COL6A3, were critical to the pathogenesis of tenosynovial giant cell tumor, findings since confirmed by others [9-11]. These genetic events are present in only a small minority of the cells within tenosynovial giant cell tumor (2\%-16\%), supporting a "field effect" model of tumorigenesis [9].

Localized tenosynovial giant cell tumors are benign with a capacity for non-destructive local recurrence. Recurrences are more common in diffuse-type tenosynovial giant cell tumor; metastases are extremely rare [4, 12]. Malignant tenosynovial giant cell tumor have been defined by Enzinger and Weiss as lesions (1) consisting of benign tenosynovial giant cell tumor coexisting with sarcoma (primary malignant tenosynovial giant cell tumor), or (2) representing sarcomatous recurrence of previously diagnosed benign tenosynovial giant cell tumor (secondary malignant tenosynovial giant cell tumor) [2]. Bertoni et al. [13] defined these lesions in somewhat less strict manner, including tumors showing morphological features similar to malignant tenosynovial giant cell tumor even without simultaneous or prior tenosynovial giant cell tumor. Malignant tenosynovial giant cell tumors are extremely rare and relatively poorly understood $[4,5,13-28]$.

We studied a series of 10 malignant tenosynovial giant cell tumors, defined by the Enzinger and Weiss criteria, with the aim of better understanding their natural history, morphological and immunohistochemical features, and molecular genetic pathogenesis.

\section{Material and Methods}

This study was approved by the Institutional Review Board at Mayo Clinic. All available routinely stained and immunohistochemistry slides of 12 cases previously diagnosed as "malignant tenosynovial giant cell tumor" were retrieved from our institutional and consultation archives and rereviewed by two of the authors (AA and ALF). Prior biopsy slides from two cases were also reviewed. The number of hematoxylin and eosin-stained slides per case varied from 8 to 30. Following re-review, two cases were not felt to show convincing evidence of origin from benign tenosynovial giant cell tumor and were excluded, leaving a final study population of ten cases. Clinical information including age, sex, anatomic location, and follow-up data were obtained by directly contacting the primary pathologist at the original institution for consultation cases, or by reviewing medical records for patients treated at Mayo Clinic. Radiographic images were reviewed when available. The sarcomatoid areas were evaluated for growth pattern, cytological features, the presence of necrosis, background matrix, and 

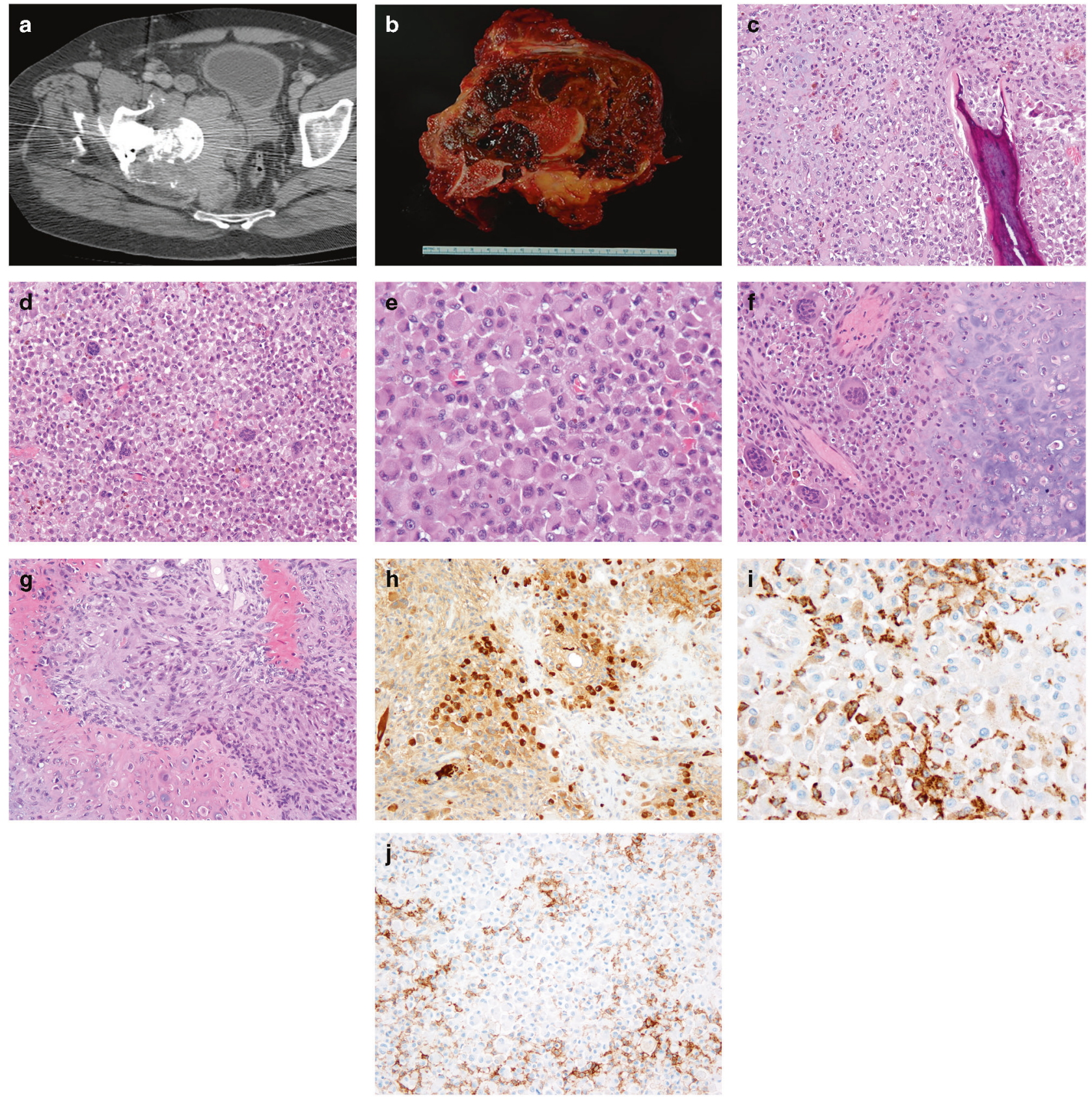

Fig. 1 Malignant tenosynovial giant cell tumor of the pelvis in a 64year-old man. Axial CT scan showed a poorly circumscribed, large, heterogeneous soft mass eroding into the hip (a). The tumor formed a large, destructive, hemorrhagic mass centered on the hip joint and extending into the surrounding soft tissues (b). The initial needle biopsy showed bone invasion by typical-appearing tenosynovial giant cell tumor, characterized by a heterogeneous admixture of small histiocytes, occasional large mononuclear cells, multinucleated osteoclast-like giant cells, and siderophages (not shown). In addition to areas of typical tenosynovial giant cell tumor, the resection specimen showed large areas with a destructive, sheet-like proliferation of large,

unusual histologic features. Mitotic rates in the area of highest mitotic activity were recorded per ten high power fields (HPF). Tumors were considered "primary" when monotonous, mononuclear large cells producing an osteoid-like hyalinized matrix (c and d). Higher power view of these highly atypical large mononuclear cells (e). In areas the tumor showed production of relatively mature cartilage, reminiscent of that seen in chondroid tenosynovial giant cell tumors of the temporomandibular joint (f). Other parts of the tumor resembled a fibroblastic osteosarcoma (g). By immunohistochemistry, the large mononuclear cells were clusterinpositive, with near-total loss of clusterin expression in sarcomatous foci (h). The mononuclear cells were negative for histiocytic markers, including CD163 (i) and CD11c (j)

there was a coexisting benign tenosynovial giant cell tumor and "secondary" if there was a confirmed prior diagnosis of tenosynovial giant cell tumor. 

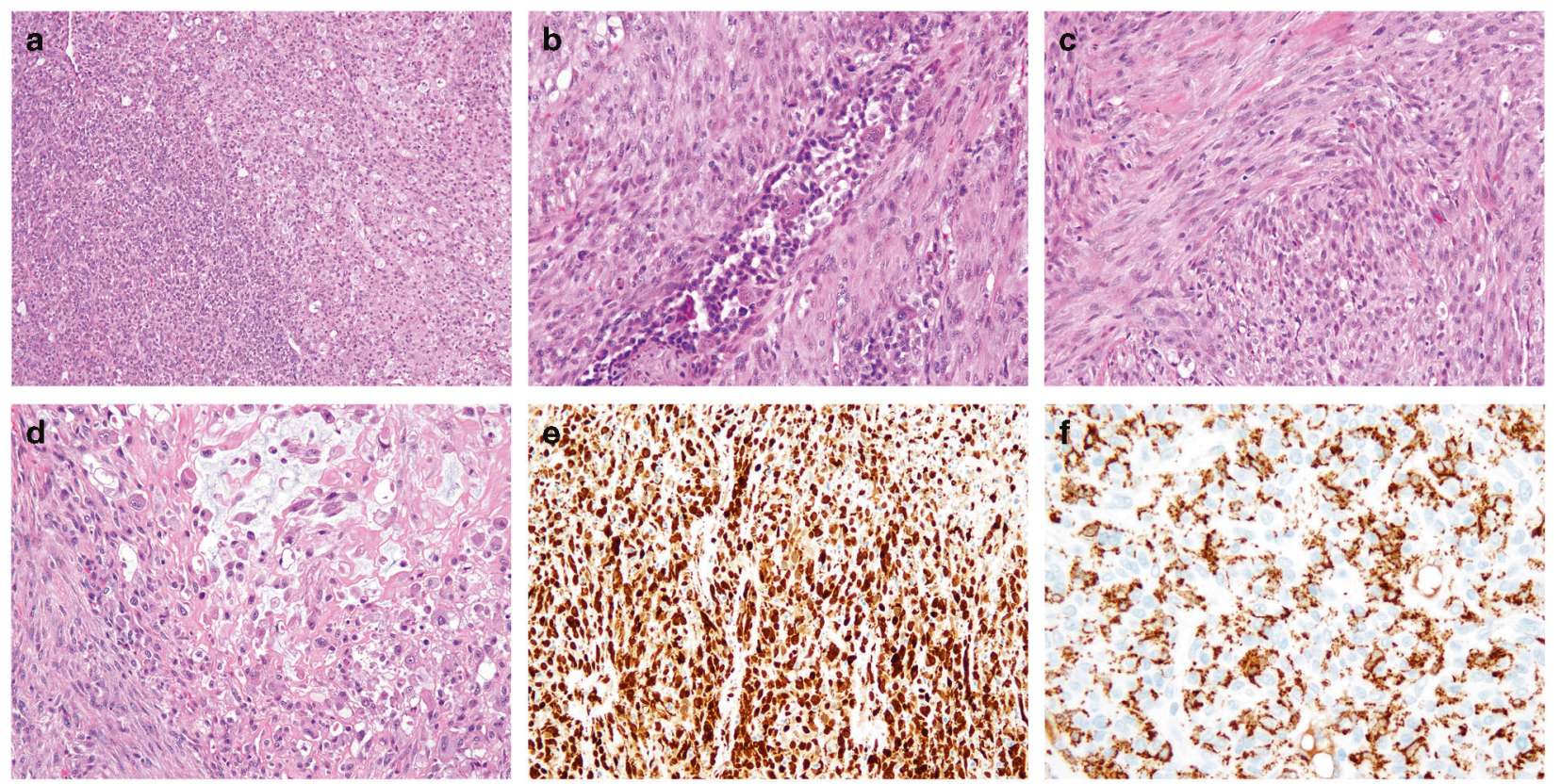

Fig. 2 Malignant tenosynovial giant cell tumor of the wrist in a 46year-old man. Areas of both typical tenosynovial giant cell tumor (left) and sarcoma (right) were present (a). Higher power view showing small nests of typical tenosynovial giant cell tumor surrounded by a fibrosarcoma-like spindle cell proliferation (b). Much of the sarcomatous portions of this tumor resembled adult-type fibrosarcoma (c), although myxofibrosarcoma-like differentiation was also present (d). Sheets of malignant large mononuclear cells were diffusely clusterin-positive (e) and negative for CD163 (f)
Immunohistochemistry was performed on representative formalin-fixed paraffin-embedded tissue sections using antibodies directed against desmin (Leica, Novocastra, New Castle, UK, clone DE-R-11, 1:50-1:100), clusterin (Millipore, Temecula, CA, clone 41D, 1:100), CD163 (Leica, clone 10D6, 1:200), CD68 (Dako, Denmark, clone KP1, 1:50-1:100), CD11c (Leica, clone 5D11, 1:100), and receptor activator of nuclear factor- $\mathrm{KB}$ ligand) (RANKL; Abcam, Cambridge, MA, 1:200). Appropriate positive and negative controls were used.

Fluorescence in situ hybridization (FISH) was performed on formalin-fixed paraffin-embedded tissue from eight cases using a previously reported protocol [29], scoring system, and a customized CSF1 break-apart probe. For FISH analysis, areas of the glass slides that contained predominantly sarcomatous-appearing tumor were circled and scored.

\section{Results}

\section{Clinical features}

The clinicopathologic features of the ten patients with malignant tenosynovial giant cell tumor are summarized in Table 1. Cases occurred in seven males and three females with a median age of 60 years (range 26-72 years). The tumor involved the ankle $(n=1)$, finger/toe $(n=3)$, wrist $(n=1)$, pelvic region $(n=3)$, leg $(n=1)$, and thigh $(n=1)$. Two tumors were extra-articular and eight were intraarticular. Two patients (cases 3 and 8 ) had a prior biopsy showing benign tenosynovial giant cell tumor, 5 and 15 months before identification of their malignant tenosynovial giant cell tumor, respectively. No patient was known to have received prior radiation therapy.

\section{Radiologic features}

On magnetic resonance imaging (MRI), the tumors were described as large lobulated heterogeneous soft tissue masses with numerous areas of dark signal on $\mathrm{T} 1$ and $\mathrm{T} 2$, and variable cystic changes. Some tumors showed involvement of the underlying bone (Fig. 1a).

\section{Pathologic features}

Grossly, the tumors were described as large, fleshy, and poorly circumscribed with areas of hemorrhage and necrosis (Fig. 1b). Histologically, all cases showed definite areas of typical tenosynovial giant cell tumor, with small histiocytes, larger mononuclear cells with eosinophilic cytoplasm and intracytoplasmic hemosiderin, siderophages, osteoclast-like giant cells, foamy macrophages, and hyalinized collagen, 

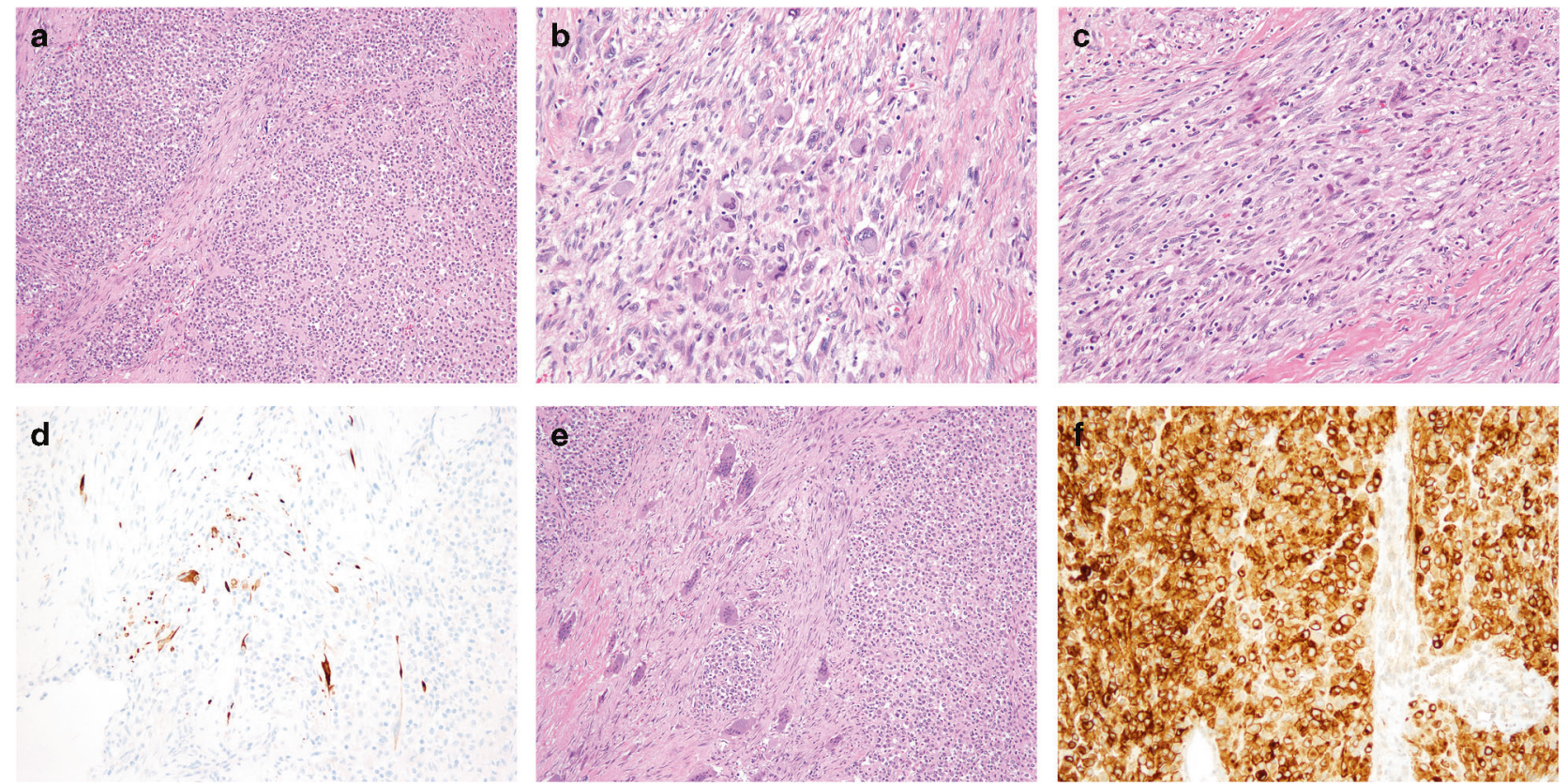

Fig. 3 Malignant tenosynovial giant cell tumor of the thigh in a 32year-old man, showing both benign-appearing (left) and sarcomatous (right) features (a). Clusters of highly atypical large mononuclear cells were present (b) as were fibrosarcoma-like spindle cell areas (c).
Occasional desmin-positive malignant large mononuclear cells were present (d). Clusters of very large osteoclast-like giant cells were also seen (e) and the sarcomatous areas were diffusely positive for RANKL (f) either in a previous biopsy from the same location or admixed with the malignant component (Figs 2a, b, 3a). The malignant areas varied in appearance. In two cases, isolated mononuclear cells with high nuclear grade and mitotic activity were identified within otherwise-typical tenosynovial giant cell tumor, and formed larger masses of similar-appearing malignant cells with brisk mitotic activity (Fig. 1c-e, 3b, 4d). In seven cases, these nodules of malignant mononuclear cells gradually evolved into pleomorphic spindle cell sarcoma, sometimes showing myxoid change and resembling myxofibrosarcoma, and in other cases showing more abundant collagen production, as seen in adult-type fibrosarcoma (Fig. 2b-d, 3C, 4f). One malignant tenosynovial giant cell tumor was composed of sheets of monotonous, large, eosinophilic cells with high nuclear grade, growing in part in a hyalinized, osteoid-like matrix, with areas showing overt heterologous osteocartilaginous differentiation (Fig. 1f and 1g). Skin invasion was present in one case (Fig. 4a). Small histiocytes, siderophages, and foamy macrophages were greatly reduced in number in sarcomatous areas. A variable number of osteoclasts were present in malignant areas, with some tumors showing clusters of very large osteoclast-like giant cells (Fig. 3e). Mitotic activity ranged from 2 to 34 mitoses per $10 \mathrm{HPF}$ (mean 18/10 HPF) in the malignant-appearing areas. Geographic necrosis was observed in four cases. Destructive invasion of bone was present in one case (Fig. 1c).

\section{Immunohistochemistry}

In all cases, areas of benign tenosynovial giant cell tumor showed three distinct cell populations: (1) numerous small histiocytes showing diffuse expression of CD163, CD68, and CD11c, (2) larger clusterin-positive mononuclear cells, and (3) scattered desmin-positive mononuclear cells, sometimes showing dendritic morphology. This cellular heterogeneity was largely lost in malignant tenosynovial giant cell tumor, which universally contained foci composed almost exclusively of clusterin-positive, malignantappearing mononuclear cells, lacking expression of CD163, CD68, and CD11c (Figs. 1h-j, 2e, 2f, 4c, 4e). Desmin was occasionally positive in malignant-appearing large mononuclear cells (Fig. 3d). Much smaller numbers of benignappearing histiocytes (positive for CD163 and other macrophage markers) were present in malignant-appearing areas. Osteosarcoma-like, fibrosarcoma-like, and myxofibrosarcoma-like foci were essentially entirely negative for clusterin, desmin, and histiocytic markers (Fig. 4g). Seven cases were tested for RANKL expression, and in all cases scattered positive large mononuclear cells were present within areas of benign tenosynovial giant cell tumor. In malignant areas, RANKL was positive in both the large mononuclear cells and in spindle cell sarcomatous foci, with variable intensity (five cases with moderate to strong expression; two cases with weak expression) (Fig. 4f). 

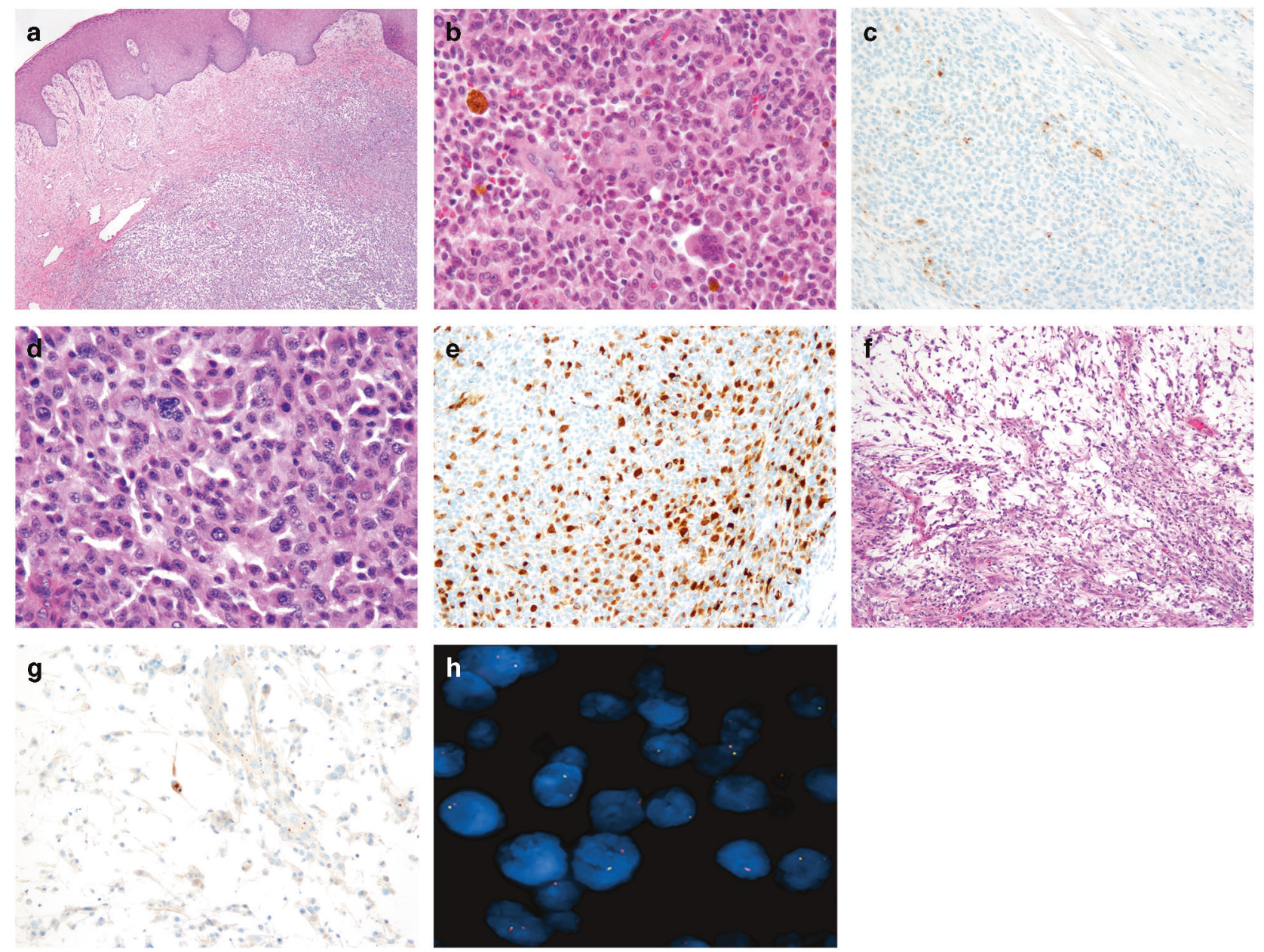

Fig. 4 Malignant tenosynovial giant cell tumor occurring in the ankle of 60-year-old man, with extensive invasion of the overlying skin (a). Areas of benign tenosynovial giant cell tumor were present (b), containing rare clusterin-positive large mononuclear cells (c). In contrast, nodules of malignant large mononuclear cells (d) were much more diffusely clusterin-positive (e). In addition, this tumor showed

\section{Molecular cytogenetics}

Likely owing to specimen fixation, only two of eight tested cases were evaluable by FISH; both showed an unbalanced rearrangement of the CSF 1 locus (cases 3 and 4 ) in $25 \%$ and $30 \%$ of the cells, respectively (Table 2) (Fig. 4h).

\section{Treatment and follow-up}

One case was too recent for meaningful follow-up. Followup information, including treatment information was available for the remaining nine patients. All patients had tumor resection. Two patients received post-operative radiation therapy to control local disease. One patient received four cycles of post-operative chemotherapy with ifosfamide, adriamycin, and cisplatin. One patient received seven cycles of denosumab. Clinical follow-up (9 patients; range myxofibrosarcoma-like differentiation (f), with near-total loss of clusterin expression (g). Fluorescence in situ hybridization, performed on a sarcomatous focus of the tumor, showed the tumor cells to have retained a single $3^{\prime}$ CSF1 signal (red), while losing the $5^{\prime}$ signal (green), indicating an unbalanced rearrangement (h)

0.5-66 months; mean 20 months) disclosed local recurrences in 3 patients $(0.5,6$, and 21 months after initial diagnosis), and pulmonary metastases in 3 patients $(6,6$, and 29 months after initial diagnosis). One patient with pulmonary metastases also had lymph node metastases. At the time of last follow-up, four patients were alive without evidence of disease, two were alive with disease, and three patients had died of disease.

\section{Discussion}

To the best of our knowledge, the first case of malignant tenosynovial giant cell tumor was described by Castens et al. [14], in their 1979 report of a 48-year-old woman with a sarcoma arising from a pre-existing tenosynovial giant cell tumor of the foot. Subsequently, fewer than 40 cases have 
Table 2 Previously reported malignant tenosynovial giant cell tumors

\begin{tabular}{|c|c|c|c|c|c|c|}
\hline Study & $\begin{array}{l}\text { No. of } \\
\text { cases }\end{array}$ & Sex & Age (s) & Location (s) & Metastases & Follow-up \\
\hline Castens et al. [14] & 1 & $\mathrm{~F}$ & 48 & Foot & Thigh, groin & AWD \\
\hline Ushijima et al. [15] & 1 & M & 59 & Knee & Thigh, lymph node & AWD \\
\hline Nielsen et al. [16] & 1 & M & 67 & Knee & Pelvic, sacrum & DOD \\
\hline Abdul-Karim et al. [5] & 1 & $\mathrm{~F}$ & 43 & Knee & No & ANED \\
\hline Shinjo et al. [17] & 1 & $\mathrm{~F}$ & 72 & Hip & $\begin{array}{l}\text { Bladder, pelvis, } \\
\text { lung }\end{array}$ & DOD \\
\hline Bertoni et al. [13] & 8 & $3 \mathrm{M} / 5 \mathrm{~F}$ & $12-79$ & Knee, foot, cheek, thigh & $\begin{array}{l}4 \text { lung, } 1 \text { lymph } \\
\text { node }\end{array}$ & 4 DOD \\
\hline Kalil et al. [18] & 1 & $\mathrm{~F}$ & 21 & Ankle & $\begin{array}{l}\text { Lung and lymph } \\
\text { node }\end{array}$ & DOD \\
\hline $\begin{array}{l}\text { De Saint Aubain Somerhausen } \\
\text { et al. [6] }\end{array}$ & 6 & $1 \mathrm{M} / 5 \mathrm{~F}$ & $21-58$ & $\begin{array}{l}\text { Hand, wrist, thigh, elbow, knee, sacrum, } \\
\text { paravertebral }\end{array}$ & $\begin{array}{l}1 \text { lung, } 1 \text { lymph } \\
\text { node }\end{array}$ & $1 \mathrm{DOD}$ \\
\hline Layfield et al. [19] & 2 & $1 \mathrm{M} / 1 \mathrm{~F}$ & $24-65$ & Hip, knee & No & $1 \mathrm{DOD}$ \\
\hline Wu et al. [20] & 1 & M & 27 & Forearm & No & ANED \\
\hline Bhadra et al. [21] & 3 & $1 \mathrm{M} / 2 \mathrm{~F}$ & $53-67$ & Knee,leg & No & $1 \mathrm{DOD}$ \\
\hline Oda et al. [22] & 1 & $\mathrm{~F}$ & 53 & Sacrum & Lymph node & AWD \\
\hline Li et al. [23] & 7 & $3 \mathrm{M} / 4 \mathrm{~F}$ & $39-78$ & $\begin{array}{l}\text { Ankle, knee, forearm, suprapopliteal, } \\
\text { supracubital, leg, thigh }\end{array}$ & $\begin{array}{l}1 \text { lung, } 1 \text { lymph } \\
\text { node }\end{array}$ & $1 \mathrm{DOD}$ \\
\hline Yoon et al. [24] & 1 & M & 29 & Temperomandibular joint & Lung & AWD \\
\hline Imakiire et al. [25] & 1 & $\mathrm{~F}$ & 56 & Knee & Vertebra, pelvis & AWD \\
\hline Kondo et al. [26] & 1 & $\mathrm{~F}$ & 58 & Buttock & Lung & AWD \\
\hline Theunissen et al. [27] & 1 & M & 66 & Wrist & No & ANED \\
\hline Richman et al. [28] & 1 & $\mathrm{~F}$ & 55 & Leg & Lung, lymph node & DOD \\
\hline Alexiev et al. [32] & 1 & M & 57 & Knee & Lung/pleura & AWD \\
\hline
\end{tabular}

$A N E D$ alive with no evidence of disease, $A W D$ alive with disease, $D O D$ died of disease, $F$ female, $M$ male

been reported in the literature $[4,5,13,15-28]$, as summarized in Table 2. Applying the strict criteria for malignant tenosynovial giant cell tumor proposed by Enzinger and Weiss [2], we have identified ten cases of malignant tenosynovial giant cell tumor, representing only a tiny fraction of the tenosynovial giant cell tumors seen in our institutional and consultation practices. In general, the clinicopathological features of our cases are similar to those of previously described malignant tenosynovial giant cell tumor, with most tumors occurring in the lower extremities of middle aged to older adults; we did however observe a male predominance, in contrast to prior reports that have consistently noted these tumors to be somewhat more common in women [4, 13, 21, 23]. Radiographically, malignant tenosynovial giant cell tumor appeared as large, lobulated soft tissue masses with numerous areas of dark signal and variable cystic change on T1 and T2 MRI scans; a subset of tumors demonstrated involvement of the underlying bone.

The natural history of malignant tenosynovial giant cell tumor is aggressive with high potential for metastasis to regional lymph nodes and distant locations. Of the previously reported cases, 12 (30\%) patients developed pulmonary metastasis $[4,13,17,18,23,28,30], 8(20 \%)$ had lymph node involvement [4, 13, 15, 18, 22, 23, 28], 6 (15\%) developed distant metastasis to thigh, pelvis, vertebral, and sacrum [5, 14-17, 25, 30], and 33\% died of disease $[4,13,16-19,21,23,28,30]$. Similarly, in our series, three patients had lung metastases, one developed lymph node metastasis, and three died of disease. The etiology of malignant tenosynovial giant cell tumor is unclear, although some previously reported cases occurred following therapeutic irradiation, an association not noted in the present study.

The morphologic appearance of the sarcomatous component in our cohort varied, echoing previous reports which have described "fibrosarcoma-like," "myxofibrosarcomalike," "malignant fibrous histiocytoma-like," "giant cell tumor-like," and "osteosarcoma-like" patterns [13, 20, 23]. The "giant cell tumor-like" pattern reported by Bertoni et al. [13] appears to correspond to cases consisting chiefly of clusters of malignant large mononuclear cells. In all cases, we observed areas that retained the overall cytoarchitecture of benign tenosynovial giant cell tumor, but showed in addition malignant-appearing mononuclear cells with high nuclear grade and mitotic activity, present as isolated cells 
within otherwise benign-appearing zones and forming nodules and sheets of varying size. In a subset of cases, these nodules of malignant large mononuclear cells transitioned into areas showing morphologic features of myxofibrosarcoma or adult-type fibrosarcoma. One unusual malignant tenosynovial giant cell tumor was composed of sheets of monotonous, eosinophilic, large mononuclear cells with high nuclear grade, growing in part in a hyalinized, osteoid-like matrix, and in other areas showing heterologous osteocartilaginous differentiation. The morphological features of this tumor were somewhat reminiscent of the chondroid tenosynovial giant cell tumors that may be seen in the temporomandibular joint [31], although with clearly malignant cytology.

Only a relatively small number of studies have studied malignant tenosynovial giant cell tumor by immunohistochemistry $[4,23,26,28,32]$ and, in general, these studies have not attempted to specifically define the immunophenotype of the various cell types that comprise these lesions. For example, Alexiev et al. [32] and Kondo et al. [26] have reported malignant tenosynovial giant cell tumor to be positive for CD68 and/or CD163 (both studies) and clusterin (Alexiev), but do not state whether these results pertain to the background histiocytes or the large mononuclear cells. Li et al. [23] noted two cases of malignant tenosynovial giant cell tumor to contain occasional desminpositive cells, felt to represent malignant tumor cells. Desmin-positive dendritic cells are seen in many ordinary tenosynovial giant cell tumor, in particular those of diffuse type [4, 33], and appear to represent a subset of the clusterin-positive large mononuclear cells [34].

For these reasons, we have attempted to carefully discriminate the immunophenotypes of the large mononuclear cells and other cell populations in malignant tenosynovial giant cell tumor. Our results strongly suggest that the malignant cells of malignant tenosynovial giant cell tumor are derived from the clusterin-positive large mononuclear cells found in benign tenosynovial giant cell tumor and in normal synovium, and thought to represent synoviocytes. The large mononuclear cells and normal synoviocytes have been previously shown to have an identical immunophenotype in most instances, with uniform expression of clusterin (a chaperone glycoprotein involved in lipid recycling and apoptosis [35-37]) and podoplanin, more variable expression of desmin, and absent expression of CD163 [34, 38]. In contrast, we did not observe expression of macrophage-related markers (CD163, CD11c, and CD68) in the large mononuclear cells present in benign-appearing zones of these tumors, or in clusters of malignant large mononuclear cells. Desmin was occasionally positive in the malignant large mononuclear cells. Desmin expression is a variable feature of the mononuclear cells of tenosynovial giant cell tumor, and although occasional cases contain very large numbers of such cells, mimicking a myogenic sarcoma, most do not. It is unclear why some synoviocytes in tenosynovial giant cell tumor show this "double positive" phenotype and others do not, but diffuse desmin expression does not seem to be a common finding in malignant tenosynovial giant cell tumor. Finally, clusterin expression is entirely lost in areas showing spindle cell sarcomatous morphology, a phenomenon suggesting "dedifferentiation" in these foci.

As tenosynovial giant cell tumors very frequently contain osteoclast-like giant cells, we evaluated these tumors for RANKL expression. RANKL is perhaps best known for its role in the pathogenesis of giant cell tumor of bone, where is its highly expressed by neoplastic mononuclear stromal cells and stimulates recruitment of osteoclastic cells from blood-born mononuclear osteoclast precursor cells that differentiate into multinucleated osteoclast-like giant cells [39-41]. RANKL expression does not appear to have been previously evaluated in tenosynovial giant cell tumor, although overexpression of RANKL is known to be present in rheumatoid arthritis, where it is thought to be produced by synovial fibroblasts [42]. We identified scattered RANKL-positive mononuclear cells within areas of benignappearing tenosynovial giant cell tumor, with much more diffuse expression in malignant areas. Clusters of very large osteoclast-like giant cells were seen in some malignant tenosynovial giant cell tumor, although not in the numbers seen in giant cell tumor of bone. One patient in this series has been treated empirically with Denosumab, reportedly with stabilization of his locally unresectable disease.

The synoviocytic origin of the malignant cells in malignant tenosynovial giant cell tumor is also supported by the genetic findings of this and other studies. As noted above, the neoplastic nature of benign tenosynovial giant cell tumor has been supported by recent studies showing recurrent genetic abnormalities including frequent rearrangement of 1p11-13 and the CSF1 locus [9, 43-45], with in situ hybridization localizing these rearrangements to a small minority of mononuclear cells within the tumor [9, 45]. Double immunolabeling experiments for CSF1 and CD163 have demonstrated little overlap between cell types expressing these markers, indicating that the neoplastic cells of tenosynovial giant cell tumor do not show a macrophage phenotype [9], a finding also supported by the present study. Huang et al. [46] have demonstrated CSF1mRNA expression by in situ hybridization in five of six studied cases, with $C S F 1$ rearrangement in one case. Our finding of unbalanced $C S F 1$ rearrangement in $>25 \%$ of cells in two successfully evaluated cases provides further evidence that the malignant component of malignant tenosynovial giant cell tumor is derived from CSF1 rearranged, clusterinpositive synoviocytes. The presence of $C S F 1$ rearrangements and CSF1 overexpression in malignant tenosynovial 
giant cell tumor also suggests a potential role for inhibitors of CSF1 and CSFR1 in the treatment of patients with this aggressive disease; CSFR1 inhibitors have shown some promise in the treatment of patients with unresectable benign diffuse-type tenosynovial giant cell tumor [47].

In summary, we have studied the clinicopathological, immunohistochemical, and molecular cytogenetic features of ten strictly defined malignant tenosynovial giant cell tumor, the largest series to date. Our study confirms the highly aggressive behavior of these very rare sarcomas and strongly supports their origin from synoviocytes. Although there are obviously excellent reasons not to propose the terms "synovial sarcoma" or "synovial cell sarcoma" to replace the term "malignant tenosynovial giant cell tumor," recognition of the synovial nature of these lesions and the role of CSF1/CSFR1, and possibly RANKL, in their pathogenesis furthers our understanding of these tumors, and may ultimately prove to have therapeutic implications.

\section{Compliance with ethical standards}

Conflict of interest The authors declare that they have no conflict of interest.

\section{References}

1. Jaffe HL, Lichtenstein L, Sutro CJ. Pigmented villonodular synovitis, bursitis and tenosynovitis. Arch Pathol. 1941;31:731-65.

2. Goldblum JR, Folpe AL, Weiss, SW. Benign tumors and tumorlike lesions of synovial tissue. In: Enzinger and Weiss's soft tissue tumors. (eds Goldblum JR, Folpe AL, Weiss SW.) 6 ed. Elsevier; Philadelphia, PA, USA 2014. p. 766-79.

3. Ushijima M, Hashimoto H, Tsuneyoshi M, Enjoji M. Giant cell tumor of the tendon sheath (nodular tenosynovitis). A study of 207 cases to compare the large joint group with the common digit group. Cancer. 1986;57:875-84.

4. Somerhausen NS, Fletcher CD. Diffuse-type giant cell tumor: clinicopathologic and immunohistochemical analysis of 50 cases with extraarticular disease. Am J Surg Pathol. 2000;24:479-92.

5. Abdul-Karim FW, el-Naggar AK, Joyce MJ, Makley JT, Carter JR. Diffuse and localized tenosynovial giant cell tumor and pigmented villonodular synovitis: a clinicopathologic and flow cytometric DNA analysis. Hum Pathol. 1992;23:729-35.

6. de Saint Aubain Somerhausen N, van de Rijn M. Tenosynovial giant cell tumor, localized type and tenosynovial giant cell tumor, diffuse type. In: Fletcher CDM, Bridge JA, Hogendoorn PCW, Mertens F, editors. WHO Classification of Tumours of Soft Tissue and Bone. Lyon, France: IARC Press; 2013. p. 100-3

7. Vogrincic GS, O'Connell JX, Gilks CB. Giant cell tumor of tendon sheath is a polyclonal cellular proliferation. Hum Pathol. 1997;28:815-9.

8. Young JM, Hudacek AG. Experimental production of pigmented villonodular synovitis in dogs. Am J Pathol. 1954;30:799-811.

9. West RB, Rubin BP, Miller MA, et al. A landscape effect in tenosynovial giant-cell tumor from activation of CSF1 expression by a translocation in a minority of tumor cells. Proc Natl Acad Sci USA. 2006;103:690-5.
10. Morris SW, Valentine MB, Shapiro DN, et al. Reassignment of the human CSF1 gene to chromosome 1p13-p21. Blood. 1991;78:2013-20.

11. Moller E, Mandahl N, Mertens F, Panagopoulos I. Molecular identification of COL6A3-CSF1 fusion transcripts in tenosynovial giant cell tumors. Genes Chromosomes Cancer. 2008;47:21-5.

12. Choong PF, Willen $\mathrm{H}$, Nilbert M, et al. Pigmented villonodular synovitis. Monoclonality and metastasis--a case for neoplastic origin? Acta Orthop Scand. 1995;66:64-8.

13. Bertoni F, Unni KK, Beabout JW, Sim FH. Malignant giant cell tumor of the tendon sheaths and joints (malignant pigmented villonodular synovitis). Am J Surg Pathol. 1997;21:153-63.

14. Castens HP, Howell RS. Maglignant giant cell tumor of tendon sheath. Virchows Arch A Pathol Anat Histol. 1979;382:237-43.

15. Ushijima $M$, Hashimoto $H$, Tsuneyoshi $M$, et al. Malignant giant cell tumor of tendon sheath. Report of a case. Acta Pathol Jpn. 1985;35:699-709.

16. Nielsen AL, Kiaer T. Malignant giant cell tumor of synovium and locally destructive pigmented villonodular synovitis: ultrastructural and immunohistochemical study and review of the literature. Hum Pathol. 1989;20:765-71.

17. Shinjo K, Miyake N, Takahashi Y. Malignant giant cell tumor of the tendon sheath: an autopsy report and review of the literature. Jpn J Clin Oncol. 1993;23:317-24.

18. Kalil RK, Unni KK. Malignancy in pigmented villonodular synovitis. Skelet Radiol. 1998;27:392-5.

19. Layfield LJ, Meloni-Ehrig A, Liu K, Shepard R, Harrelson JM. Malignant giant cell tumor of synovium (malignant pigmented villonodular synovitis). Arch Pathol Lab Med. 2000;124:1636-41.

20. Wu NL, Hsiao PF, Chen BF, Chen HC, Su HY. Malignant giant cell tumor of the tendon sheath. Int J Dermatol. 2004;43:54-7.

21. Bhadra AK, Pollock R, Tirabosco RP, et al. Primary tumours of the synovium. A report of four cases of malignant tumour. J Bone Jt Surg Br. 2007;89:1504-8.

22. Oda Y, Takahira T, Yokoyama R, Tsuneyoshi M. Diffuse-type giant cell tumor/pigmented villonodular synovitis arising in the sacrum: malignant form. Pathol Int. 2007;57:627-31.

23. Li CF, Wang JW, Huang WW, et al. Malignant diffuse-type tenosynovial giant cell tumors: a series of 7 cases comparing with 24 benign lesions with review of the literature. Am J Surg Pathol. 2008;32:587-99.

24. Yoon HJ, Cho YA, Lee JI, Hong SP, Hong SD. Malignant pigmented villonodular synovitis of the temporomandibular joint with lung metastasis: a case report and review of the literature. Oral Surg Oral Med Oral Pathol Oral Radiol Endod. 2011;111: e30-6.

25. Imakiire N, Fujino T, Morii T, et al. Malignant pigmented villonodular synovitis in the knee - report of a case with rapid clinical progression. Open Orthop J. 2011;5:13-6.

26. Kondo R, Akiba J, Hiraoka K, et al. Malignant diffuse-type tenosynovial giant cell tumor of the buttock. Pathol Int. 2012;62:559-64.

27. Theunissen CI, Bras J, Lienden KP, Obdeijn MC. Malignant giant cell tumor in the carpal tunnel: a case report and review of literature. J Wrist Surg. 2013;2:271-5.

28. Richman DM, Bresler SC, Rosenthal MH, Howard SA. Malignant tenosynovial giant cell tumor of the leg: a radiologic-pathologic correlation and review of the literature. J Clin Imaging Sci. 2015;5:13.

29. Medeiros F, Erickson-Johnson MR, Keeney GL, et al. Frequency and characterization of HMGA2 and HMGA1 rearrangements in mesenchymal tumors of the lower genital tract. Genes Chromosomes Cancer. 2007;46:981-90.

30. Kahn LB. Malignant giant cell tumor of the tendon sheath. Ultrastructural study and review of the literature. Arch Pathol. 1973;95:203-8. 
31. Hoch BL, Garcia RA, Smalberger GJ. Chondroid tenosynovial giant cell tumor: a clinicopathological and immunohistochemical analysis of 5 new cases. Int J Surg Pathol. 2011;19:180-7.

32. Alexiev BA, Tumer Y, Yang GY. Malignant tenosynovial giant cell tumor with CDKN2A/B genomic alteration: a histological, immunohistochemical, and molecular study. Hum Pathol. 2017;63:144-8.

33. Folpe AL, Weiss SW, Fletcher CD, Gown AM. Tenosynovial giant cell tumors: evidence for a desmin-positive dendritic cell subpopulation. Mod Pathol. 1998;11:939-44.

34. Boland JM, Folpe AL, Hornick JL, Grogg KL. Clusterin is expressed in normal synoviocytes and in tenosynovial giant cell tumors of localized and diffuse types: diagnostic and histogenetic implications. Am J Surg Pathol. 2009;33:1225-9.

35. Jones SE, Jomary C. Clusterin. Int $\mathrm{J}$ Biochem Cell Biol. 2002;34:427-31.

36. Grogg KL, Lae ME, Kurtin PJ, Macon WR. Clusterin expression distinguishes follicular dendritic cell tumors from other dendritic cell neoplasms: report of a novel follicular dendritic cell marker and clinicopathologic data on 12 additional follicular dendritic cell tumors and 6 additional interdigitating dendritic cell tumors. Am J Surg Pathol. 2004;28:988-98.

37. Grogg KL, Macon WR, Kurtin PJ, Nascimento AG. A survey of clusterin and fascin expression in sarcomas and spindle cell neoplasms: strong clusterin immunostaining is highly specific for follicular dendritic cell tumor. Mod Pathol. 2005;18:260-6.

38. Talmon G, Wake L, Muirhead D. Podoplanin and clusterin are reliable markers of nonneoplastic synovium at various sites. Int $\mathbf{J}$ Surg Pathol. 2013;21:587-90.

39. Rutkowski P, Gaston L, Borkowska A, et al. Denosumab treatment of inoperable or locally advanced giant cell tumor of bone - multicenter analysis outside clinical trial. Eur J Surg Oncol. 2018;44:1384-90.

40. van der Heijden L, Dijkstra PD, van de Sande MA, et al. The clinical approach toward giant cell tumor of bone. Oncologist. 2014;19:550-61.

41. Suda T, Takahashi N, Martin TJ. Modulation of osteoclast differentiation. Endocr Rev. 1992;13:66-80.

42. Romas E, Gillespie MT, Martin TJ. Involvement of receptor activator of NFkappaB ligand and tumor necrosis factor-alpha in bone destruction in rheumatoid arthritis. Bone. 2002;30:340-6.

43. Nilsson M, Hoglund M, Panagopoulos I, et al. Molecular cytogenetic mapping of recurrent chromosomal breakpoints in tenosynovial giant cell tumors. Virchows Arch. 2002;441:475-80.

44. Sciot R, Rosai J, Dal Cin P, et al. Analysis of 35 cases of localized and diffuse tenosynovial giant cell tumor: a report from the Chromosomes and Morphology (CHAMP) study group. Mod Pathol. 1999;12:576-9.

45. Cupp JS, Miller MA, Montgomery KD, et al. Translocation and expression of CSF1 in pigmented villonodular synovitis, tenosynovial giant cell tumor, rheumatoid arthritis and other reactive synovitides. Am J Surg Pathol. 2007;31:970-6.

46. Huang HY, West RB, Tzeng CC, et al. Immunohistochemical and biogenetic features of diffuse-type tenosynovial giant cell tumors: the potential roles of cyclin A, P53, and deletion of $15 \mathrm{q}$ in sarcomatous transformation. Clin Cancer Res. 2008;14:6023-32.

47. Cassier PA IA, Gomez-Roca CA, Le Tourneau C, Toulmonde M, Cannarile MA, Ries C, et al. CSF1R inhibition with emactuzumab in locally advanced diffuse-type tenosynovial giant cell tumours of the soft tissue: a dose-escalation and dose-expansion phase 1 study. Lancet Oncol. 2015;16:949-56. 